\title{
Climate Challenges of Small Island Developing States: Cases of Tuvalu, Seychelles and Barbados
}

\author{
Lidija Kos - Stanišić ${ }^{1, *}$ Đana Luša ${ }^{1}$ Borna Zgurić ${ }^{1}$ \\ ${ }^{I}$ Faculty of Political Science, University of Zagreb \\ "Corresponding author. Email: lidija.kos-stanisic@fpzg.hr
}

\begin{abstract}
Small Island Developing States (SIDS) present a group of small island countries that tend to share similar sustainable development challenges, which except from small, but growing populations, limited resources, and extensive dependence on international trade, include remoteness, sensitivity to natural disasters and vulnerable environments. For these islands climate change is an everyday reality and nowhere in the world are its implications more immediate than on SIDS. This particularly includes sea level rise, contaminated water, increased coral bleaching, rise of the global average temperatures, high levels of unemployment and consequently brain drain and other migrations. The paper focuses on three distinctive geographic regions by analyzing climate challenges of following SIDS: Barbados (the Caribbean), Seychelles (Africa) and Tuvalu (Asia and Pacific). Although aforementioned states share similar destiny as a result of smallness and remoteness, as well as most of the climate challenges, at the same time they display completely different policies in addressing them. While Tuvalu is SIDS most affected by climate changes which endanger its survival and is mostly focused on preserving its statehood, Barbados and Seychelles are more prone to concrete policy responses by promoting renewable energy and blue economy.
\end{abstract}

Keywords: Climate Change, SIDS, Vulnerability, Migration, Climate Activism.

\section{INTRODUCTION}

Three small island developing states (SIDS) Tuvalu from the Asia-Pacific region, Seychelles from Africa, and Barbados from the region of Latin America and Caribbean - have much in common, but also many things that sets them apart. Although they are thousands of kilometres distant from each other - Barbados and Seychelles are almost 13.000 kilometres distant from one another, Seychelles and Tuvalu 13.400 kilometres, and Tuvalu and Barbados 13.700 kilometres - all three tropical island states are former British colonies that gained their independence in the period from 1966 to 1978. With the former capital they are tied with their membership in Commonwealth. Geostrategically, Barbados and Seychelles have a significant location first is located in the neighbourhood of the superpower USA, while the other is located in the middle of the Indian Ocean on the way towards the Sues Canal - alas Tuvalu is one of the most distant countries of the world. Tourism, alongside offshore sector and services, makes the largest segment of the Barbados' and Seychelles' GDP. Fisheries makes the largest segment of Tuvalu's GDP, while remittances from abroad make big chunks of GDP both for Tuvalu and Barbados. It should also be noted that Seychelles are one of the larger players in the segment of fisheries in the world.

The main common denominator of analysed three states is represented by climate change, which affects every day lives of their citizens and survival of state, as well as policy answers to environmental challenges. Focus of SIDS is placed on mitigation and adjustment to the aftermath of climate change. The main research question is whether Tuvalu, Seychelles and Barbados share identical threats to environmental security and which policies do they use to fight consequences of climate challenges to their security?

To give an answer this question we apply the comparative method or rather the comparative research design. More specifically, we use one of the most common comparative approaches utilised for the small $n$ 
studies like ours, namely the most similar systems design (MSSD). The purpose of MSSD is to simulate an experimental design, which is why it is often called a quasi-experimental design, by comparing the most similar countries that have different outcomes in specific segments that are being researched. This is how we learn why these countries, that are very similar, in the end have different policy outcomes for instance [1].

In the first section the paper addresses differences between traditional and new security challenges, among which the focus is mostly on climate change and its consequences on SIDS. The second section analyses challenges faced by Tuvalu fighting hard not to sink and trying to preserve some of the elements of its statehood. In the third and the fourth section in contrast to Tuvalu's responses the paper problematizes Seychelles' and Barbados' policies of fighting against climate change. By comparing responses to climate change of three analysed island states from three different geographic regions, the paper aims at detecting similarities and differences between SIDS faced by the new security threats.

\section{THEORETICAL FRAMEWORK: NEW SECURITY CHALLENGES OF SIDS - THE EXAMPLE OF CLIMATE CHANGE}

In the traditional sense of the word, as well in the sense of the realistic approach to IR and security studies, under security we perceive security from military threats. To put it simply - under threats we perceive enemy troops on our borders. In this sense we are concerned with the questions when and how are we going to use our military forces to deal with that threat [2]. However, in the world of today's national and international security, alongside with security policies, we are dealing with a lot more threats which are in a nutshell anything but military threats. Security issues which we are dealing than are, for instance, migrants on our borders, a pandemic of a nasty virus, economic problems, or the collapse of our environment. According to the Copenhagen school of security studies, which goes hand in hand with the constructivist turn in IR and security studies, security threats are threats that the citizens of a country perceive as threats. This means that not all citizens and not all countries will perceive the same issues as security threats. Alas, threats can vary from classic, military threats, to utilization of weapons of mass destruction, to economic issues, migrations, epidemics and pandemics, weakening of polities and political systems, terrorism, to climate change and so on, and so on ([3]; [2]; [4]).

Every state has the main national interest - to survive. All states strive to it. However, as stated before, not all states perceive the same challenges to their statehoods. Environmental challenges are one of those new threats. Moreover, depending on the gravity of the threat there are three levels of threats that are imposed by the environment - those not caused by man (volcano eruptions or earthquakes); those caused by man, but which do not endanger the humanity as a whole (pollution of the sea or unchecked extraction of some natural resources); and finally, those caused by man which endanger the humanity as a whole, one of them most definitely being rising sea levels [5]. In the paper we will focus on this third level. In a nutshell there is nothing new in the human thought that our environment can endanger us and our polities. All throughout the history man has perceived its environment as a potential danger to him [5]. However, during the Cold War environmental threats were securitized for the first time, alas they stayed in the shadow of the Cold War and the threat that the nuclear weapons pose. Only after the end of the Cold War the military securitization started to wain in a way, while securitization of the environmental threats begin to blossom [5].

Alongside international and national, we also differ the human security which tells us that alongside threats to nation states the individuals that inhabit those nation states face different threats. For example, Tavares (2014: 1) believes that human security does not rule out the "traditional" national security because, although they do not share the same wholesome security agenda, they are often complementary and go hand in hand together. The concept of human security originated in 1994 when the UN published the Human Development Report which for the first time moved the security focus from nation states to individuals. This eventually resulted with the creation of Commission on Human Security (CHS) in 2001. Namely, this was an answer to the complexity and intertwining of old and new transnational security threats (poverty, ethnic violence, human trafficking, climate change, pandemics, terrorism, sudden economic and financial crises, and so on), as well as trying to reach a consensus on a mashup of development, human rights and national security. CHS (2003) states that the aim of human security is to protect all human life, which means a "top-down" approach that recognizes that humans cannot control the possible threats, and that primarily the states, and in a lesser degree international and nongovernment organizations and private sector, is in charge of their protection. We differentiate economic, food, health, personal, community, political and environmental security which envisages environmental degradation, resource depletion, natural disasters and pollution [6] But, all types of security, or insecurity, are very much interconnected.

As climate changes present one of the main causes of environmental insecurity, we first need to focus on defining them. According to Article 1 of the UN Framework Convention on Climate Change, (UN, 1992: 3) climate change is "a change of climate which is attributed directly or indirectly to human activity that 
alters the composition of the global atmosphere and which is in addition to natural climate variability observed over comparable time periods." Already the first assessment report of the Intergovernmental Panel on Climate Change (IPCC) from 1990 anticipated that small island and atoll states will be gravely endangered by the aftermaths of climate change, especially by the rising sea level. Two years later the United Nations Framework Convention on Climate Change (UNFCCC) noted that in its article 4.8 .

Belle and Bramwell [7] state that the IPCC and UNFCCC have projected that the rise of average global temperature from 1.4 to 5.8 degrees Celsius in the period from 1999 to 2100 will cause the sea level to rise from 9 to 88 centimetres, alongside more and more common intense and extreme climate phenomena. According to IPCC small island states, due to the high degree of vulnerability and low capacity to adapt, present the group of states that are exposed to an extremely high risk. Rising sea level would cause to SIDS erosions of coasts and beaches, and penetration of salted wated into the reservoirs of clear water, destruction of coastal agriculture and human settlements, destruction of tourism which in most cases is the main staple of economy. According to UNDP [8] more than a decade ago it was agreed that adaptation to climate change remains the key priority for SIDS.

Small Island Developing States (SIDS) is the name for the group of small island states that share similar challenges like small populations, limited resources, distance, exposure to natural catastrophes, external vulnerabilities, dependence on international trade and volatile surroundings. SIDS have 57 member states which differ by the number and density of population, geographical characteristics and development, but that share vulnerabilities which prevent them in achieving development and minimise their perspectives for growth. Most member states are both members of different regional organisations like Caribbean Community, Pacific Islands Forum, Indian Ocean Commision, alongside Alliance of Small Island States (AOSIS), which lobbies and negotiates in the name of SIDS within the framework of UN [9].

SIDS were recognised in 1992 by the UN as a special group which shares the common risk of climate change, especially due to the "dominance of economic sectors that are reliant on the natural environment" [10]. SIDS are organised into AOSIS, while some member states, such as Tuvalu, also belong to the group of the least developed countries (LDC). SIDS comprise 20 percent of the UN members, alas only five percent of the world's population [11]. They are often described as "frontlines of climate change","hot spots of climate change", or as being "canaries in the coalmine". AOSIS represents a fairly powerful group for negotiations within the UNFCCC which highlights their negligible contributions to man-made climate change, but how on the other hand they are mostly affected by them [10].

At the Copenhagen conference in 2009 AOSIS advocated 45 percent emission cuts by 2020 and limiting global temperature increase to below 1.5 Celsius, and in its activism Tuvalu especially was standing out [12].

Ourbak and Magnan [11] state how SIDS, by utilising AOSIS, played the key role in raising awareness on climate change on the international level by advocating the "strong climate action". At the same time, they represented the key group in negotiations during 21st Conference of the Parties to the United Nations Framework Convention on Climate Change (COP21) and the Paris agreement coming into force. After the Paris agreement was signed, the main problem was its ratification, and to come into force 30 days should have passed after minimally 55 signatories ratified it which make at least 50 percent of the world's population. Fully aware that they do not fulfil the necessary preconditions, they wanted to demonstrate the gravity of the agreement and encourage the ratification. Fiji was the first country that ratified the agreement, followed by the Marshall Islands, Palau and Maldives. Furthermore, Fiji was among the first countries that ratified the Kyoto protocol [11] which came into force in 2005 while the UNFCCC bounded the industrialised countries and economies on cutting down the greenhouse gas emissions [13].

Despite their heterogeneity, they have created a common diplomatic discourse and demonstrated leadership "in raising ambition to reduce greenhouse gas emissions to help secure an ambitious long-term temperature goal of limiting global warming to below $1.5^{\circ} \mathrm{C}$, and advanced the complex debate on loss and damage" [11]. Except their common diplomatic strategy, talented negotiators and advisors, the group "flushed out" a few "vocal" political leaders, among them the prime minister of Barbados Freundel Stuart (2010-2018) and the prime minister of Tuvalu Enele Sopaga (2013-2019).

Focus of the SIDS is placed on adjustment and mitigation of the climate change consequences by the way of Nationally Determined Contributions (NDCs) for cutting down the greenhouse gases. SIDS emit negligible amounts of greenhouse gases, most of the originating from imported fossil fuels. For that reason, more and more they are turning to utilisation of renewable energy sources [10], as we will see on the example of Barbados. SIDS are very vocal when it comes to promoting "the inclusion of loss and damage in international climate discourses" within UNFCCC, and are highly connected to the matters of climate justice which perceives the climate change not just a political but as an ethical question as well. The literature on climate justice stipulates for the SIDS mostly 
redistributive implications of climate change on and the notable North-South division, which is especially visible in the UNFCCC negotiations [10]. After the G20 meeting of the energy and environment ministers held in 2021, which resulted with no agreement on climate, AOSIS praised the states "which have stood up for a more ambitious target" [14].

\section{ENVIRONMENTAL CHALLENGES OF TUVALU}

Tuvalu symbolises the "group of eight", or in other words eight inhabited islands. There are in total nine islands (one non-inhabited), of which six are atolls with the total land surface of $26 \mathrm{~km} 2$. The highest altitude does not surpass three meters [15], which makes Tuvalu the most environmentally vulnerable state in the AsiaPacific area. Next to the climate change Tuvalu is also in danger due to bad management of liquid waste, pollution, lack of fertile soil and drinking water. Thanx to the La Niña phenomenon, which affects the entire area due to abnormal rise of sea levels and rainy seasons, Tuvalu is facing with intense floods as well [16].

Precisely the rising sea level represents for Tuvalu the gravest of all threats cause by the climate change. Just in the course of the $20^{\text {th }}$ century the sea lever rose between 0.1 and 0.2 metres, which resulted in the loss of the coastal area, floods and salinization of the sources of drinking water. Furthermore, Tuvalu always had to struggle with the extreme weather conditions due to its location in the cyclone belt, which made it vulnerable to tropical storms and cyclones. The worst cyclone was the one from 1972 the aftermath of which was that 800 people lost their homes while some atolls were completely annihilated [15].

Climate change is mostly visible on the coral reefs which represent the most important natural treasure of the islands. Their slow growth does not guarantee the possibility of resisting the rise of temperatures of the sea as well as of the rise of the concentration of carbon dioxide [15]. Not only those coral reefs are a home to numerous animal species, but they are also utilised for development of new medical drugs, tourism, and most importantly to protect the shores. When it comes to Tuvalu, it has modest proportions of shores, and additional challenge represents the exploitation of sand and corals. Important element of islands' development represents a healthy eco system if we keep in mind that around 80 percent of the population depends on agriculture and fisheries. With the rising sea level comes the salinization of the sources of water and land, while drinking water is not only endangered by the climate change, but by local pollution as a result of growth of population and inefficient environmental management as well [15].
Mentioned climate and environmental challenges are a serious threat to the survival of small island state, which at the same time belongs to the group of least developed countries. As the smallest of any independent states its GDP growth in the past was volatile and this is expected to continue in the future. With the lack of human and technological capacities, the only feasible solution finds itself in migration, both internal and external. Already a large number of the population moved to Funafuti, the atoll where capital is located, on which in 1999 lived roughly 40 percent of the population, and the population density amounted to 347 people per $\mathrm{km} 2$ [15]. As one of possible solutions that presented itself in regard of Tuvalu vanishing is its population seeking the status of environmental refugees in New Zeeland and some other states.

We need to stress how small states like Tuvalu do not have any autonomy in managing the climate change due to the fact it is a global problem, which mostly depends on the policies of developed states. With the aim to put pressure on permanent members of the UN's Security Council, states which are affected by the climate change express their claims in documents and speeches on climate change [16]. In that manner, during the Copenhagen summit in the December of 2009 Tuvalu demonstrated its political activism by claiming the legally bounding agreements and more aggressive action, which many of the vulnerable states, from small island to sub-Saharan states, supported. At the same time Tuvalu suggested a new protocol according to which more substantial cuts to the global emissions of the greenhouse gases would be made. Tuvalu also stressed how rich countries caused the global warming which directly implies their responsibility for remediation. In what measure Tuvalu profited as an advocate for combating the climate change testifies the statement of the Secretary General of the UN António Guterres who in May of 2019, while visiting Tuvalu, expressed his admiration for Tuvalu's resistance to climate change, for which it needs the support of the whole world. "We must take urgent \#ClimateAction to save Tuvalu - and save the world", the SecretaryGeneral tweeted. "We must stop Tuvalu from sinking and the world from sinking with Tuvalu"[17].

In December of 2012 during the climate negotiations in Doha the representatives of small island states characterised the progress of greenhouse gas reductions as inadequate, and in the report of United Nations Environment Program and Pacific Regional Environment Program grievences of small island states which are highly susceptible to climate change were highlighted alongside with the coordinated actions that should be taken to address the environmental needs on all levels [18].

In the mid 2015 six small island states (Vanuatu, Kiribati, Tuvalu, Fiji, Solomon Islands and Philippines) 
published a manifest on climate change People's Declaration for Climate Justice, drawing from a lawsuit against large multinational corporations on the charges of pollution, degradation of the ecosystem and other effects on the climate. Furthermore, during the meeting of the leaders of Pacific Island Development Forum in September of 2015 the Suva Declaration on Climate Change was adopted, by which the importance of restricting the rise of temperature is being acknowledged (Patrick, 2019). In mid-December of 2015 during the COP of the UN's Framework convention on climate change in Paris a historical agreement was adopted. On one side it was praised as a victory of environmental activists and diplomats, and on the other it was understood only as an initiative and not as a perfect first step into a sustainable future (Ibid.) Among other things, the states managed to agree upon the need to restrict the rise of global temperature by 1.5 degrees Celsius. The aforementioned discussion, warnings about the ice caps going to melt and with them connected the rising sea level, utilized the leaders of the small island states, especially the prime minister of Tuvalu Enele Sopoaga. Considering the fact that most small island states face exodus, AOSIS demanded that the developed world acknowledges its responsibility for irreparable damage it has done which for a result had climate change. The coalition of small island states (Kiribati, Tuvalu, Fiji and Marshall Islands) designed some sort of a "Marshall Plan" for the Pacific by which it would be invested to renewable energy, protection of the coast, preservation of the culture, economic relief, and plans for migration and resettlement of the population. As a result of this efforts New Zeeland, in March of 2018, became the first country in the world that acknowledged the devastating effect on climate change as a basis for asylum seeking [18].

Further demonstration of regional activism of small island pacific states regarding the climate change played out in the August of 2019 during the talks within the framework of Pacific Island Forum in Tuvalu. The most intense debate was held around Australian delegation insisting that carbon dioxide is not being mentioned in the documents, limiting the global warming below 1.5 degrees Celsius and announcing no emission strategy until 2050. The solution can be seen in climate diplomacy which would enable one or more great powers access to exclusive economic zones, right to build military bases or expand the area of the navigation of fishing vessels. On the other hand, this could ensure the funds for climate resilience and measures of adjustment as well as ambitious climate devotion of some of the leading states in the world (Patrick, 2019).

Regarding all of the afore mentioned segments of the climate change that reflect within the shape of environmental challenges, the question on statehood of Tuvalu poses itself. According to the Montevideo Convention there are four base elements of statehood: permanent population, defined territory, government and the capability of the state to interact with other actors in international relations (Montevideo Convention on the Rights and Duties of States, 2021). The group of small island states is especially exposed to the challenge of survival as a consequence of climate change. Permanent population, as one of the segments of statehood, is under threat in regard that migrations are cause by the rising sea level, drought, lack of water and food [19]. Alongside population the survival of the territory of the aforementioned states is also at stake. The question poses itself what happens with the state that permanently loses its population and territory, or in other words is she still a state after it "sinks"?

However, there is no universally accepted definition of a state and neither are criterium defined by the Montevideo Convention self-sustaining segments of statehood [20]. Wittering away of the state as a consequence of nature's changing was unforeseen scenario that was not taken into account during the creation of international law, which regulated the creation and succession of states. James Crawford [21] believes how a presumption of a continuity of statehood exists, justifying this claim with the fact that even in the case when a state gains or loses territory which is much larger than the area of the previous state territory this will not affect the statehood. As an example, he mentions the government of Belgium in the temporary exile to London between 1940 and 1944. In the case of small island state until the so called "sinked" state keeps the other characteristics of statehood it should be recognised as sui generis state with existing territorial sea on the area of the previous land. As Crawford [21] stresses, states do not necessary disappear with significant changes in territory, population or government. The process of wittering away of the state in international law cannot be forced, it is voluntary [20].

Many examples demonstrate the flexibility of the application of Montevideo Convention, however if we do not take in to account the continuity of the statehood, a question poses itself again where will the population of the states that are sinking as a result of climate change and consequences to environment go. Namely, there are no legally binding agreements that protect the climate migrants [22]. Maxine Burkett offered one of the possible solutions which would demand a recognition of ex-situ nation, or a de-territorialised state as a state of which population is scattered all over the world. An example of such a state is Kiribati whose strategy of migration is towards Australia and New Zeeland. As another possible solution that poses itself is floating architecture, or rather a construction of floating cities [22]. Ex-situ nation would imply an existence of a sovereign state which has all the sovereign rights, which would protect its population that was forces to abandon its original place of stay and which would serve as a 
political entity even when its populations leaves [23]. The government of the ex-situ state would govern on a permanent location and manage the affairs of the state distantly. The most important task of such a government would be preservation of all elements of the state such as culture, ties between its people and the safety of its citizens. The ex-situ nation, next to sustainable participation of endangered state in international community, guarantees the preservation of the state as consequence of migration as well.

Such de-territorialisation of states could exist in international law, which recognises how sovereignty of a nation could be separate from the territory. Two examples of de-territorialised states are Knights of Malta and the Holy See. Small island states as Tuvalu and Maldives considered the idea of a de-territorialised state. For example, in 2001 Tuvalu approached Australia with the suggestion to relocate its population there, which was rejected. An agreement was reached with New Zeeland which guarantees that New Zeeland would accept only 75 people per year, which means that most of the population would stay unprotected.

Although a government in exile would be a feasible solution to sinking small island states, international law does not address the situation of a permanent government in exile. Namely, governments in exile were a result of colonisation, not climate change. Question poses itself, does such a government ensures control over its territory and maritime zone indefinitely. International law is unable to determine the term which a government in exile has to function outside its territory, especially when the territory is below the surface of the sea, and with a realisation that it would never recover [24].

Thus, as the most feasible solution to preserving statehood poses itself a combat against global warming. However, it is not very likely that substantial change will occur. Subsequently, another feasible solution is to construct some sort of coastal defence mechanisms which would prevent its erosion, which again for small island states is not financially feasible. A solution presents itself in constructing artificial islands on which the population could relocate. However, artificial islands do not have the same status as natural ones in the international law, which again affects the rights of the state in an exclusive economic zone. Furthermore, it is unclear whether artificial islands fulfil the territorial criteria of statehood. Facing this challenge of sinking as an aftermath of climate and environmental change, Tuvalu faces a fight for survival or rather staying afloat.

\section{ENVIRONMENTAL CHALLENGES OF SEYCHELLES}

Seychelles are a small island developing state (SIDS) situated in the Indian Ocean along the eastern coast of the African continent. Seychelles are comprised of over hundred islands while only three are inhabited Mahé, Praslin and La Digue. Around 94.000 Seychellois live on these three islands, and the land area in total of Seychelles amounts to $455 \mathrm{~km} 2$ [25]. Furthermore, Seychelles are a micro-island-state highly dependable on ocean resources, and moreover to them climate change presents a high risk [25]. According to Seychelles' INDC [26] they want to cut down Greenhouse gas emissions till 2025 by 21,4 percent, or rather until 2030 by 29 percent "relative to their baseline emissions". In the same document the Seychelles are stressing how they are emitting only 0.0003 of total global emissions [26].

Due to this reasons Seychelles managed to become a diplomatic leader in the promotion of the sustainable development of the oceans, especially trough the concept of blue economy, which was highlighted in their INDC [26]. In its basic definition, blue economy means a sustainable utilisation of oceans resources with the aim of economic growth, improvement of people's lives and how they do business that go hand in hand with the improvement of the health of the ocean's ecosystems [27]. In the year 2017 UN organised an international conference on the topic of blue economy which was unofficially dubbed "the Seychelles conference". The concept of the blue economy is the main theme of their ocean diplomacy. The African Union even adopted it and implemented in it's African integrated maritime strategy 2050 [25]. Furthermore, Seychelles have the second largest exclusive economic maritime zone, proclaimed in 1977 in all of Africa - it has around 1,4 million square kilometres. At the same time, it is the $24^{\text {th }}$ largest exclusive economic maritime zone in the world. It should be noted that Seychelles are the 8th largest manufacturer of canned tuna in the world ([28]; [25]; [29]).

In the implementation of the blue economy, or rather their Strategic plan for blue economy, Seychelles are being aided by Commonwealth, which they are the member of. The Strategic plan was adopted in the January of 2018 and it is aligned with the Sustainable Development Agenda 2030, Aichi Target 11 Convention on biological diversity, and lastly with the Paris Agreement on climate changes. To implement the Strategic Plan the Government of Seychelles had to create a new department for the blew economy, which was later joined to the Ministry of fisheries, thus transforming it to Ministry of fisheries and blue economy. The minister who heads the Ministry is also in charge for the coordination and implementation of the Strategic Plan both in the country and abroad. Alas, although Seychelles are the world's leader in promotion of the sustainable development of the oceans, on its own it does not have the resources to fully implement the blue economy inside its own borders, let alone in the international arena. Thusly, Commonwealth plays the 
role of an active partner to Seychelles in this endeavour [30].

Originally Seychelles started their international ocean activism with a fight against whaling proposing to make the Indian Ocean a safe place for whales. Although this initiative failed in the end, this was a cornerstone for Seychelles future diplomatic endeavours. Since they kickstarted their concept of the blue economy, Seychelles became a mayor international player in the field of environmental diplomacy. Seychelles were very clear in advocating this concept on the Rio+20 conference; at the 21st African Union Summit, the Tokyo International Conference on African Development and at the meeting on the African Integrated Maritime Strategy in the Seychelles, all three taking place in 2013. Furthermore, Seychelles organised a Blue Economy Summit as part of Abu Dhabi Sustainable week in 2014. Government of the Seychelles ordered and produced multiple studies on the blue economy, created a ministry of blue economy, as well as a Blue Economy Research Institute. It is easy to say that the blue economy is the main staple of Seychellois environmental diplomacy [25].

As stated before, Seychelles have been actively promoting the concept of the blue economy both regionally and internationally. For instance, Africa's Integrated Maritime Strategy 2050, the Decade of African Seas and Oceans (2015-2025), Africa Blue Economy: A policy Handbook, and lastly African Charter on Maritime Security and Safety and Development are all regional policy documents that have adopted the concept of the blue economy. All these policy documents stress the need for a regional cooperation dealing with the sustainable development of the oceans. And these are just the handful of documents that have accepted this concept [31].

The term itself was coined at the Rio +20 conference in 2012 by the SIDS countries with the aim to both improve human lives and reduce the environmental risks. Later it was also adopted by the UN as a part of its development goals [31]. In 2014 Seychelles and UAE co-hosted the Blue Economy Summit which resulted with the Abu Dhabi Declaration. The summit was attended by many heads od states and governments as well as representatives of international organisations such as FAO, UNCTAD and the President of the UN General Assembly. In the same year the UN third international conference on SIDS in Samoa took place. The conference was as well attended by a large number of heads of states and governments along with 3.500 delegates which were comprised by stakeholders from diverse sectors [31].

UN as well has adopted the concept of the blue economy and has launched the Sustainable Blue Economy Finance Initiative with the aim to financially support the implementation of the blue economy [32]. It should be also noted that the EU, or rather the European Commission, has also adopted the same concept as part of their environmental policies [33]. Thus, it could be rightly concluded that Seychelles are a true champion of the blue economy concept all around the world [31].

It should be noted that the two main staples of the Seychelles' economy are tourism and fisheries, thus it is only natural that they want to protect them at all cost since "a healthy ocean was deemed imperative for the country's future" [34]. With this in mind, the government of Seychelles declared the 30 percent of the country's ocean territory as a Marine Protected Area in 2020. Alas, in the same year the COVID-19 pandemic hit the Seychelles tourism sector hard resulting in Seychelles economy contracting by 13.8 percent. To make matters worse port Victoria had to close its "doors" for the next two years to foreign cruise ships, and total public debt rose to 80 percent. It should also be noted that port Victoria is an important outlet for different blue economy activities. Although the blue economy activities have for now been resilient and might stay that way in the future, even suggesting the possibility for the recovery of country's economy, alas this again opens an opportunity of the infringement of the blue economy and the return to the unchecked extraction of ocean's wealth [34].

\section{CLIMATE CHANGE CHALLENGES OF BARBADOS AND TRANSITION TO RENEWABLE ENERGY SOURCES}

Barbados is a small state that is located in the southeastern part of the Caribbean Sea with its land area sized $430 \mathrm{~km} 2$ and with the population size of 290.000. The island was at the end of the 20th century among the most densely populated states in the world [7], and in the 2021 it was in the 17th place [35]. Due to climate change, after the Cold War the gravest foreign policy, or more precisely security challenge that Barbados faces is the lack of environmental security. Thusly, Barbados has focused its foreign policy activities towards SIDS, the group Barbados itself is a member of, shares vulnerabilities and formulates common attitudes on climate change and coordinates foreign policy activities.

Barbados' engagement was already visible during the 1990s. It has ratified the UNFCCC in the 1994, when the first Global conference on sustainable development of small island developing states was held on Barbados, which resulted with The Barbados Programme of Action (BPOA). BPOA stressed the extreme vulnerability of SIDS to climate change, climate variabilities and rising sea levels; identified priority areas and highlighted the concrete measures needed to combat special challenges that governments of these countries are facing. The need to act fast in implementing the BPOA was stressed as well on the Millennial summit of the UN in 2000 [36]. BPOA was 
upgraded with the 2005 Mauricius strategy of implementation and was even more stressed in 2012 during the Rio de Janeiro UN conference on sustainable development. In the document The Future that we Want it was highlighted how small land surface and distance from land, lack of resources and export products, as well as exposure to global environmental challenges and foreign economic shocks, and by far the most to impact of climate change and more and more frequent environmental disasters represents a great challenge to sustainable development of SIDS. On the third international conference of SIDS, held in Samoa in 2014 , priority areas and the necessity of coordinated actions were agreed upon [8].

Climate change effects that the hurricane season is even longer and longer in the Caribbean, and the hurricanes are getting even stronger and stronger. They destroy the infrastructure, the beaches and prevent the arrival of tourists. In this manner the hurricane Dorian caused around 3.4 billion USD worth of damage to Barbados in 2019. In other words, it "ate" one quarter of the island's GDP [37]. Alongside frequent hurricanes, in 2020 the Caribbean were "diagnosed" with rising sea temperature of +0.87 degrees Celsius in comparison from 1981 to 2010 period, which made it to surpass the 2010 record of $+0,78$ degrees Celsius. Next to the rising sea levels of 3.6 millimetres in the period from 1993 to 2020, the Caribbean have surpassed the global annual average of 3.3 millimetres [38].

Barbados ratified the 2000 Kyoto Protocol, and in 2015 it adopted the Intended Nationally Determined Contribution (INDC) which on the day of Paris Agreement coming into force on the 4th of November 2016 became the first ever NDC (2015 NDC). To lead by example in international community and to demonstrate how to cut even those negligible emissions of greenhouse gases that they emit, SIDS are turning to green renewable energy. Barbados is a leader in this area. It has one of the most ambitious projects in the world regarding the energy transition and it is one of the leading manufacturers of solar water heaters in the Caribbean. Furthermore, still in 2016 it made a decision to switch to 100 percent renewable sources of energy and to achieve the zero emission by 2030 (Mead, 2021), for which it ensured in 201930 million USD from InterAmerican Development Bank [37].

However, soon Barbados realised that if it abides to the aims from the first NDS it will not be ambitious enough to "pursue efforts to limit the average temperature increase to $1.5{ }^{\circ} \mathrm{C}$ compared to preindustrial temperatures" [39]. Thusly, in the July of 2021 it updated the former NDC's. The prime minister Mottley stressed that the aim of Barbados is to be until 2030 "fossil fuel free economy", alas how that is "the aspirational target" which might need to be amended by 2025. She stipulated the other NDSs such as: "reducing the emissions from 7.7 tonnes per year per person, to 2.3 tonnes; an unconditional commitment to a fossil-fuel free electricity sector and transport by 2030; an unconditional commitment of 20 per cent reduction relative to business as usual emissions in 2025, without international support; a 35 per cent reduction relative to business as usual emissions in 2025 , but conditional on international support; an unconditional 35 per cent reduction relative to business as usual emissions in 2030, without international support; a 70 per cent reduction relative to business as usual emissions in 2030; that is conditional upon international support" (Austin, 2021). In doing so she highlighted how it is important to put more emphasis on financial adjustments and making sure to secure more substantial irrevocable funds due to the fact that loans would just raise the debts of SIDS and making them harder to achieve the sustainable development aims.

Barbados is lucky to be geographically located the way it is in the area rich with sun and wind, as well as the power of the ocean. Daily it has in avarage 8.3 hours of un and "5.6 kilowatts of solar irradiation per square meter", annual speed of wind amounts to 5.5 metres per second, while the power of the ocean can be utilised for creating energy, as well as installing "offshore wind turbines" [37].

All the above made the transition to renewable energy sources much easier. Williams [40] states how still from the oil crisis of 1974 Barbados was among the world leaders in producing "solar hot water" and that currently it is "in the top five globally for solar hot water systems per capita" and that the first "grid-scale solar farm" on the islanded came into function in 2019. Alongside solar energy, it is also planned to utilise wind as a renewable energy source. While it is easy to use the solar energy by simply putting solar cells on the roofs of the budlings, next to houses to utility-scale multimegawatt systems, utilising energy of the wind is largely underappreciated due to high investment costs longer period of investment return.

Although Barbados has no utility-scale wind operating at present, in the course of the 1980s the island was experimenting with the energy of the wind, alas 200kW Howden wind turbine showed itself as costly, noisy and unprofitable investment which was fairly quickly abandoned. Furthermore, it left bad reputation not only in Barbados but in the Caribbean as a whole, which in comparison to Pacific (one percent) and African SIDS (four percent) utilise only 0.8 percent of wind energy of their electricity generation [41]. Unfortunately, at the moment the energy from the waste and bioenergy are not being utilised, which includes the waste from the sugar cane industry. However, the Barbados National Energy Policy (BNEP) 2017-2037 anticipates their usage [42]. 


\section{CONCLUDING REMARKS}

Despite all the similarities that SIDS share, for example they all participate in environmental activism and represent impressive actors in the international forums dedicated to climate change, on the examples of Tuvalu, Seychelles and Barbados we have showed some significant differences between them. Although, the main threat that these states face are consequences of climate change, they are not of the same intensity. While Tuvalu, one of the least developed and the most remote states of the world, faces more traditional threat to its security, namely the threat of annihilation, Seychelles and Barbados face threats to human security. Thus, their policies responses for combating those threats are different. Tuvalu is mostly focused on preserving its statehood and it is fully focused on finding the solution for its problems that are in line with international law. Seychelles and Barbados do not face the danger of sinking under water in the foreseeable future they are keener to address climate change issues differently. Seychelles by sustainable development of the ocean's trough the concept of blue economy and

\section{REFERENCES}

[1] L. Todd, Teme i metode komparativne politike. Zagreb: Fakultet političkih znanosti. 2008.

[2] D. M. Snow, Thinking About National Security: Strategy, Policy, and Issues. 2016.

[3] S. Tatalović, A. Grizold, and V. Cvrtila, "Suvremene sigurnosne politike : države i nacionalna sigurnost početkom 21. stoljeća," Food Policy, no. 97, pp. 1-79, 2008.

[4] Dragutin Repinc et al., Nacionalna sigurnost Republike Hrvatske u 21. stoljeću. Zagreb: Naklada Jesenski i Turk d.o.o., 2019.

[5] Filip Ejdus, Međunarodna bezbednost - teorije, sektori i nivoi. Beograd: Službeni glasnik i Beogradski centar za bezbednosnu politiku, 2012.

[6] United Nations Trust Fund for Human Security, "HUMAN SECURITY IN THEORY AND PRACTICE Application of the Human Security Concept and the United Nations Trust Fund for Human Security Human Security Unit Office for the Coordination of Humanitarian Affairs United Nations," New York, 2009.

[7] N. Belle and B. Bramwell, "Climate Change and Small Island Tourism: Policy Maker and Industry Perspectives in Barbados," J. Travel Res., vol. 44, no. 1, pp. 32-41, Aug. 2005, doi: $10.1177 / 0047287505276589$.

[8] UNDP, "Responding to Climate Change in
Small Island Developing State,”27-Sep-2009. [Online]. Available:

https://sustainabledevelopment.un.org/content/d ocuments/960SIDS_Flyer_SEPT_27_09[1].pdf.

[9] OECD, "Small Island Developing States - SIDS - OECD." [Online]. Available:

https://www.oecd.org/dac/financing-sustainabledevelopment/development-finance-topics/smallisland-developing-states.htm.

[10] A. Thomas, A. Baptiste, R. Martyr-Koller, P. Pringle, and K. Rhiney, "Climate Change and Small Island Developing States," https://doi.org/10.1146/annurev-environ012320-083355, vol. 45, pp. 1-27, Oct. 2020, doi: 10.1146/ANNUREV-ENVIRON-012320083355 .

[11] T. Ourbak and A. K. Magnan, "The Paris Agreement and climate change negotiations: Small Islands, big players," Reg. Environ. Chang. 2017 188, vol. 18, no. 8, pp. 2201-2207, Nov. 2017, doi: 10.1007/S10113-017-1247-9.

[12] R. S. Dimitrov, "Inside UN Climate Change Negotiations: The Copenhagen Conference," Rev. Policy Res., vol. 27, no. 6, pp. 795-821, Nov. 2010, doi: 10.1111/j.15411338.2010.00472.x.

[13] United Nations, UNITED NATIONS FRAMEWORK CONVENTION ON CLIMATE CHANGE. New York, 1992.

[14] "AOSIS Responds to G20's Dissent on Climate Change Commitments - AOSIS." [Online]. Available: https://www.aosis.org/aosisresponds-to-g20s-dissent-on-climate-changecommitments/. [Accessed: 11-Nov-2021].

[15] H. Ralston, B. Horstmann, and C. Holl, "Climate change challenges Tuvalu | Germanwatch e.V.," 2004. [Online]. Available: https://germanwatch.org/en/2758. [Accessed: 11-Nov-2021].

[16] P. B. A. Braga and F. Lanza, "Globally unassisted tuvaluans affected by climate changes: Official documents, human rights and the 'no future'?," Ambient. e Soc., vol. 19, no. 4, pp. 196-179, 2016, doi: 10.1590/18094422ASOC129R1V1942016.

[17] United Nations, "Stop Tuvalu and "the world from sinking' UN chief tells island nation facing existential threat from rising seas || UN News," 17-May-2019. [Online]. Available: https://news.un.org/en/story/2019/05/1038661. [Accessed: 11-Nov-2021].

[18] Country Watch, "Tuvalu 2016 Country Review," 2016. [Online]. Available: http://www.countrywatch.com/Content/pdfs/revi ews/B466LL3L.01c.pdf. [Accessed: 11-Nov- 2021]. 
[19] Sarah M. Munoz, "What happens when a country drowns?," 01-Jul-2019. [Online]. Available: https://theconversation.com/whathappens-when-a-country-drowns-118659. [Accessed: 11-Nov-2021].

[20] U. Padmabhushan and D. Kumar, "Land ahoy?: Solutions for Statehood in a post climate change world," Völkerrechtsblog, Mar. 2020, doi: 10.17176/20200316-123019-0.

[21] J. Crawford, The creation of states in international law. Oxford: Oxford University Press, 2007.

[22] Claudia Tam, "Does an Island Lose its Statehood if it Sinks? |Earth.Org - Past | Present | Future," 25-Mar-2021. [Online]. Available: https://earth.org/will-an-island-lose-itsstatehood-if-it-sinks/. [Accessed: 11-Nov-2021].

[23] M. Burkett, "The Nation Ex-Situ: On climate change, deterritorialized nationhood and the post-climate era," Clim. Law, vol. 2, no. 3, pp. 345-374, Jan. 2011, doi: 10.3233/CL-2011-040.

[24] J. Kittel, “The Global 'Disappearing Act': How Island States Can Maintain Statehood in the Face of Disappearing Territory - CORE," Digit. Commons Michigan State Univ. Coll. Law, 2015.

[25] C. Bueger and A. Wivel, "How do small island states maximize influence? Creole diplomacy and the smart state foreign policy of the Seychelles," J. Indian Ocean Reg., vol. 14, no. 2, pp. 170-188, May 2018, doi: 10.1080/19480881.2018.1471122.

[26] "Republic of Seychelles Intended Nationally Determined Contribution (INDC) Under The United Nations Framework Convention On Climate Change (UNFCCC)," 2015.

[27] The World Bank, "What is the Blue Economy?,” 06-Jun-2017. [Online]. Available: https://www.worldbank.org/en/news/infographic /2017/06/06/blue-economy. [Accessed: 11-Nov2021].

[28] I. Kawaley, "Implications of the exclusive economic zone and EEZ management for seychelles, a small midocean Island commonwealth territory," Ocean Dev. Int. Law, vol. 29, no. 3, pp. 225-264, Jan. 1998, doi: $10.1080 / 00908329809546125$.

[29] A. Robinson, "Seychelles: Prospects, Probity and Legacy - Governance under Transnational Pressures," Round Table, vol. 108, no. 3, pp. 307-326, May 2019, doi: 10.1080/00358533.2019.1618612.

[30] The Commonwealth, "Seychelles Blue
Economy Strategic Roadmap and Implementation | The Commonwealth," 2016. [Online]. Available:

https://thecommonwealth.org/project/seychelles -blue-economy-strategic-roadmap-andimplementation. [Accessed: 11-Nov-2021].

[31] Marie-Therese Purvis, "Seychelles Blue Economy Strategy.” [Online]. Available: http://www.finance.gov.sc/uploads/files/The_B1 ue_Economy_strategy.pdf. [Accessed: 11-Nov20211 .

[32] "Sustainable Blue Finance - United Nations Environment - Finance Initiative.” [Online]. Available: https://www.unepfi.org/bluefinance/. [Accessed: 11-Nov-2021].

[33] "Sustainable blue economy." [Online]. Available: https://ec.europa.eu/oceans-andfisheries/ocean/blue-economy/sustainable-blueeconomy_hr. [Accessed: 11-Nov-2021].

[34] M. Senaratne, "Blue Economy in 2021: Perspectives from Seychelles | ORF," Observer Research Foundation, 08-Jan-2021. [Online]. Available: https://www.orfonline.org/expertspeak/blue-economy-2021-perspectivesseychelles/. [Accessed: 11-Nov-2021].

[35] World Population Review, "Barbados Population 2021 (Demographics, Maps, Graphs)," 2021. [Online]. Available: https://worldpopulationreview.com/countries/ba rbados-population. [Accessed: 11-Nov-2021].

[36] CLIMATE CHANGE SECRETARIAT (UNFCCC), "UNFCCC (2005) climate change, small island developing States," Bonn, 2005.

[37] Stephen Illes, "4 Facts About Renewable Energy in Barbados - The Borgen Project." [Online]. Available:

https://borgenproject.org/renewable-energy-inbarbados/. [Accessed: 11-Nov-2021].

[38] World Meteorological Organization, "New report shows impacts of climate change and extreme weather in Latin America and Caribbean | World Meteorological Organization," 17-Aug-2021. [Online]. Available: https://public.wmo.int/en/media/pressrelease/new-report-shows-impacts-of-climatechange-and-extreme-weather-latin-america-and. [Accessed: 11-Nov-2021].

[39] G. of Barbados, "BARBADOS 2021 UPDATE OF THE FIRST NATIONALLY DETERMINED CONTRIBUTION."

[40] Jeremy Williams, "How Barbados will reach $100 \%$ renewable energy - The Earthbound Report," 01-Dec-2020. [Online]. Available: https://earthbound.report/2020/12/01/how- 
barbados-will-reach-100-renewable-energy/. [Accessed: 11-Nov-2021].

[41] T. Rogers, M. Ashtine, R. Koon Koon, and M. Atherley-Ikechi, "Onshore wind energy potential for Small Island Developing States: Findings and recommendations from Barbados," Energy Sustain. Dev., vol. 52, pp. 116-127, Oct. 2019, doi: 10.1016/J.ESD.2019.08.002.
[42] David Ince, "FINAL DRAFT OF THE BARBADOS NATIONAL ENERGY POLICY (2017-2037)," 2017. [Online]. Available: https://energy.gov.bb/download/barbadosnational-energy-policy-bnep-20172037/? wpdmdl=1872\&refresh=618ce21f100ae 1 636622879. [Accessed: 11-Nov-2021]. 